\title{
Potent antioxidant and genotoxic effects of ammonium tetra borate in vitro
}

\author{
Fatih Caglar Celikezen ${ }^{1 *}$, Hasan Turkez ${ }^{2}$,Elanur Aydin ${ }^{3}$, Mehmet Sait Izgi ${ }^{1}$, \\ Burcin Celikezen $^{4}$
}

\begin{abstract}
Objective: Boron shows antioxidant properties with an unknown mechanism. It was aimed to evaluate the antioxidant potentials and genotoxic risk of ammonium tetra borate on human whole blood cultures for the first time in the extent of this study $(n=4)$.

Material and Methods: Ammonium tetra borate was administrated at concentrations between 1.25-1280 $\mu \mathrm{g} / \mathrm{ml}$ to cultured blood samples. The micronuclei and chromosomal aberration tests were performed to determine genotoxic effect. In addition, total antioxidant capacity and total oxidative stress levels were measured as biochemical parameters.

Results: Our results clearly provided that the all tested concentrations of ammonium tetra borate were notmutagenic. Moreover, ammonium tetra borate showed antioxidant activities at low concentrations and the total oxidative stress levels were not changed at all the concentrations of ammonium tetra borate.

Conclusion: Our data's, clearly indicated that ammonium tetra borate is not mutagenic and it has remarkable antioxidant potential in vitro.

Keywords: Ammonium tetraborate, Chromosomal aberrations, micronucleus test, genotoxicity, human blood cells
\end{abstract}

\section{Introduction}

Naturally, boron (B) exists in physical environment and in foods (1). Humans are exposed to boron through diet, from drinking water, and from some consumer products including soaps and detergents, body building supplements, bottled water, fertilizers, pesticides, preservatives, and cosmetic, oral hygiene, eye care, and deodorant products (2). It is absorbed by mucous membranes of the vagina, anus, mouth and the epithelial cells of gastrointestinal tissues. Humans and animals may absorb the whole of supplemental inorganic boron (3), and B homeostasis is basically maintained by urinary excretion (4). Some in vitro and epidemiological studies indicate that B may make important contributions to human health $(5,6,7)$. Newnham (8) and Chapin et al. (9) showed that B is essential mineral for bones and joints. And, boron can improve arthritis, lipid profiles of plasma and brain function (10). In addition, Turkez et al. (11) reported the protective role of borax on aluminium induced liver injury in rats. Moreover, some researchers reported that boron compounds have beneficial effects on cancer $(12,5,13)$.
Celikezen et al. (14) reported that potassium borate supported antioxidant activity at low concentrations in cultured human blood cells. In different studies reported in the literature, B compounds have exhibited antioxidant properties $(15,16,17,18)$. Moreover, several boron compounds (boric acid, borax, kernite and probertite) showed protection against genotoxic effects in cultured human lymphocytes $(19,20)$.

Borates are commonly used in the manufacture of glass and ceramics, soaps and detergents, fertilizers, herbicides and cosmetics (21). Numerous boron compounds have been synthesized and, although borates are used in many industrial areas, their genotoxic and antioxidant potentials have not been studied in cultured human blood cells. Therefore, micronuclei (MN) assay and chromosomal aberrations (CA) tests were performed to determine genotoxic effects of ammonium tetra borate on human lymphocytes. Furthermore, total antioxidant capacity (TAC) and total oxidative status (TOS) assays were examined to evaluate oxidative capacity in cultured human blood cells.

Received: 27-11-2015, Accepted 01-12-2015, Available Online: 08-12-2015

1 Bitlis Eren University, Faculty of Science and Letter, Dept. of Chemistry, Bitlis, Turkey

2 Erzurum Technical University, Faculty of Science, Dept. of Molecular Biology and Genetics, Erzurum, Turkey

3 Erzurum Technical University, Faculty of Science, Dept. of Biology, Erzurum, Turkey.

4 Firat University, Faculty of Veterinary Science, Dept. of Pharmacology.

*Corresponding Author: Fatih Caglar Celikezen E-mail: celikezen@gmail.com 


\section{Material and Methods}

Production of ammonium tetra borate tetrahydrate

In the present study, the used ATT (NH4)2B4O7.4H2O was produced according to the following equation by Demir et al. (22) in addition titrimetric method and thermal analysis were used to determine the $\mathrm{B} 2 \mathrm{O} 3$ content and it was found about $\%$ 52,85 (23). The product mass was 263,2 and purity of the product was about $\geq \% 99,5$.

\section{$2 \mathrm{NH} 4 \mathrm{OH}+4 \mathrm{H} 3 \mathrm{BO} 3(\mathrm{aq}) \rightarrow(\mathrm{NH} 4) 2 \mathrm{~B} 4 \mathrm{O} 7.4 \mathrm{H} 2 \mathrm{O}$}

\section{Blood sampling}

Whole heparinized human blood from five healthy non-smoking donors between the ages 22 and 25 with no history of exposure to any genotoxic agent was used in our experiments. Questionnaires were obtained for each blood donor to evaluate exposure history. In all the volunteers involved in this study, haematological and biochemical parameters were analysed and no pathology was detected. A various concentrations $(0,1.25,2.5,5,10,20,40,80,160$, $320,640$ and $1280 \mathrm{mg} \mathrm{L}-1)$ of AT were applied into blood cultures. The dose range was selected according to the previous study (24). MN and CA rates were assessed in peripheral lymphocytes. Experiments conformed to the guidelines of the World Medical Assembly (Declaration of Helsinki). The cultures without ATT studied as control- group. Mitomycin C $(0,1 \mu \mathrm{M})$ was used as the positive control in $\mathrm{MN}$ and CA. Likewise, ascorbic acid $(10 \mu \mathrm{M})$ and hydrogen peroxide $(25 \mu \mathrm{M})$ were also used as the positive controls in TAC and TOS analysis, respectively.

\section{Cytogenetic and Micronucleus assay}

Human peripheral blood lymphocyte cultures were set up according to a slight modification of the protocol described by (25). The micronucleus test was performed by adding cytochalasin B (Sigma ${ }^{\circledR}, \mathrm{St}$ Louis, MO, USA; final concentration of $6 \mu \mathrm{g} / \mathrm{mL}$ ) after $44 \mathrm{~h}$ of culture as described by (26). At the end of the $72 \mathrm{~h}$ incubation period, the lymphocytes were fixed with ice-cold methanol: acetic acid $(3: 1)$. The fixed cells were put directly on slides using cytospin (a cytology method that is specifically designed to concentrate cells such as these that are found in small number) and stained with Giemsa. All slides were coded before scoring. The criteria for scoring micronuclei were applied as described previously by (27). At least 1000 bi-nucleated lymphocytes were examined per concentration for the presence of one, two, or more micronuclei.

\section{Chromosome aberration assay}

A $0.5 \mathrm{~mL}$ aliquot of heparinized blood was cultured in
$6 \mathrm{~mL}$ of culture medium (Chromosome Medium B; Biochrom, Berlin) with $5 \mathrm{mg} / \mathrm{mL}$ of phytohemagglutinin (PHA) (Biochrom). The cultures were incubated in complete darkness for $72 \mathrm{~h}$ at $37^{\circ} \mathrm{C}$. Two hours prior to harvesting, $0.1 \mathrm{~mL}$ of colchicine ( $0.2 \mathrm{mg} / \mathrm{mL}$, Sigma) was added to the culture flask. Hypotonic treatment and fixation were performed. To prepare slides, 3-5 drops of the fixed cell suspension were dropped on a clean slide and air-dried. The slides were stained in $3 \%$ Giemsa solution in phosphate buffer ( $\mathrm{pH}$ 6.8) for $15 \mathrm{~min}$. For each treatment, 30 well-spread metaphases were analysed to detect the presence of CA. Criteria to classify the different types of aberrations (chromatid or chromosome gap and chromatid or chromosome break) were in accordance with the recommendation of EHC (Environmental Health Criteria) 46 for environmental monitoring of human populations (28).

\section{TAC and TOS analysis}

TAC and TOS status of cell cultures were analysed using automated commercial kits (Rel Assay Diagnostics ${ }^{\circledR}$, Gaziantep, Turkey) (29).

\section{Statistical analysis}

Statistical analysis was performed using SPSS software (version 13.0, SPSS, Chicago, IL, USA). The Duncan's was used to determine whether any treatment significantly differed from controls or each other. Statistical decisions were made with a significance level of 0.05

\section{Results}

The frequencies of $\mathrm{MN}$ and $\mathrm{CA}$ on human peripheral blood lymphocyte treated with ATT are given in Figure 1 and Figure 2, respectively. In vitro exposure to ATT did not induce significant $(\mathrm{p}>0.05)$ increases in $\mathrm{MN}$ and $\mathrm{CA}$, regardless of the dose, indicating the non-genotoxic nature of ATT.

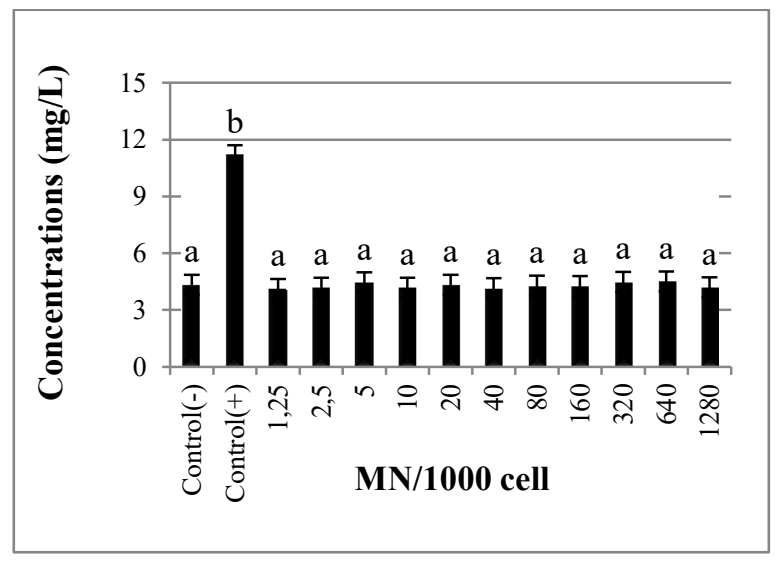

Figure 1. The frequencies of $\mathrm{MN}$ in human lymphocyte treated with varying concentrations of ammonium bi-borate over $72 \mathrm{~h}$. (Positive control: Mitomycin C (10-7 M). Values are expressed as mean \pm SD for five cultures in each group. The bars are shown by different letter are significantly different from each other at a level of $5 \%$.) 


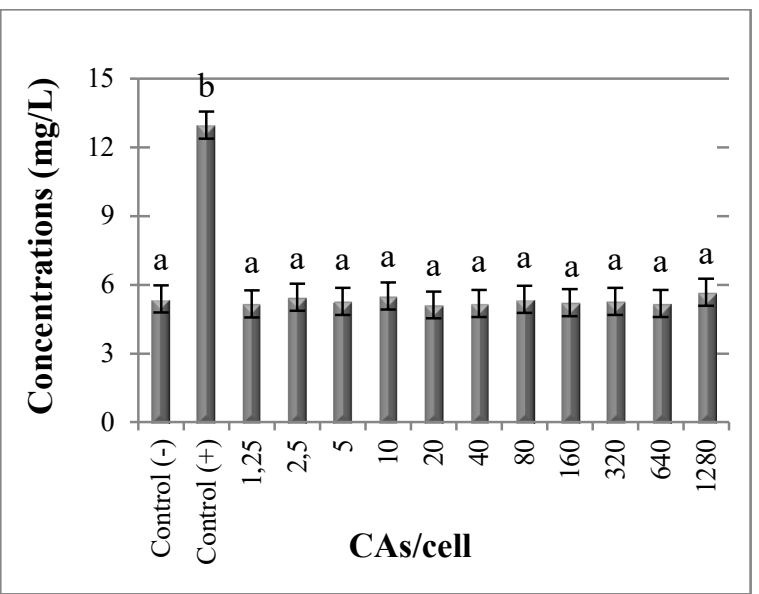

Figure 2. The CA values in human lymphocyte treated with varying concentrations of ammonium bi-borate over $72 \mathrm{~h}$. Abbreviations are as in Figure 1.

Table 1 reflects the comparison of oxidantantioxidant profile of ATT on cultured human blood cells. As seen from the Table 1, ATT at the concentrations of $1.25,2.5,80,160,320,640$ and $1280 \mathrm{mg} / \mathrm{L}$ did not affect TAC in cultured human blood cells, increased it significantly at concentrations of 5, 10, 20 and $40 \mathrm{mg} / \mathrm{L}$ compared to control-. On the other hand, TOS levels did not change at all treated concentrations of ATT in cultured human blood cells.

Table 1. Total antioxidant capacity (TAC) and total oxidative stress (TOS) levels in cultured human blood cells exposed to ammonium biborate for $24 \mathrm{~h}$. (Positive control: ascorbic acid $(10 \mu \mathrm{M})$ and hydrogen peroxide $(25 \mu \mathrm{M})$ in TAC and TOS analysis, respectively. The bars are shown by different letter are significantly different from each other at a level of $5 \%$.)

\begin{tabular}{|c|c|c|}
\hline Treatments & $\begin{array}{c}\text { TAC mmol } \\
\text { Trolox Equiv. } \mathrm{L}^{-1}\end{array}$ & $\begin{array}{c}\text { TOS mmol } \\
\mathrm{H}_{2} \mathrm{O}_{2} \text { Equiv. } \mathrm{L}^{-1}\end{array}$ \\
\hline Control $^{-}$ & $5,96 \pm 0,61^{\mathrm{a}}$ & $12,34 \pm 2,94^{\mathrm{a}}$ \\
\hline Control $^{+}$ & $12,85 \pm 0,98^{\mathrm{c}}$ & $39,08 \pm 4,52^{b}$ \\
\hline $1,25 \mathrm{mg} / \mathrm{L}$ & $5,98 \pm 0,59^{\mathrm{a}}$ & $11,12 \pm 3,18^{a}$ \\
\hline $2,5 \mathrm{mg} / \mathrm{L}$ & $5,67 \pm 0,64^{\mathrm{a}}$ & $11,64 \pm 3,67^{\mathrm{a}}$ \\
\hline $5 \mathrm{mg} / \mathrm{L}$ & $7,45 \pm 0,72^{b}$ & $11,87 \pm 3,06^{\mathrm{a}}$ \\
\hline $10 \mathrm{mg} / \mathrm{L}$ & $8,86 \pm 0,59^{b}$ & $12,25 \pm 2,97^{\mathrm{a}}$ \\
\hline $20 \mathrm{mg} / \mathrm{L}$ & $8,28 \pm 0,64^{b}$ & $11,38 \pm 2,98^{\mathrm{a}}$ \\
\hline $40 \mathrm{mg} / \mathrm{L}$ & $8,54 \pm 0,67^{b}$ & $11,68 \pm 3,77^{\mathrm{a}}$ \\
\hline $80 \mathrm{mg} / \mathrm{L}$ & $6,04 \pm 0,79^{a}$ & $12,17 \pm 3,76^{\mathrm{a}}$ \\
\hline $160 \mathrm{mg} / \mathrm{L}$ & $5,94 \pm 0,75^{\mathrm{a}}$ & $12,55 \pm 3,16^{\mathrm{a}}$ \\
\hline $320 \mathrm{mg} / \mathrm{L}$ & $5,21 \pm 0,81^{\mathrm{a}}$ & $12,47 \pm 3,13^{\mathrm{a}}$ \\
\hline 640 mg/L & $5,17 \pm 0,72^{a}$ & $11,98 \pm 3,27^{\mathrm{a}}$ \\
\hline $1280 \mathrm{mg} / \mathrm{L}$ & $5,94 \pm 0,66^{\mathrm{a}}$ & $12,72 \pm 2,99^{\mathrm{a}}$ \\
\hline
\end{tabular}

\section{Discussion}

Studies on the potential toxicities of borates are urgent for their biosafety evaluation due to their widespread application in various fields. One of most sensitive marker tests of biosafety is genotoxicity testing, which reveals agent DNA-damaging influence (30,31). In this investigation, ATT was found to be nongenotoxic. Because, the results of our study did not show any significant increases in the ratios of the CAs and MNs in lymphocytes exposed to ATT as compared to control values. In fact, CA test is a very useful and important indicator of exposure to chemical and biological agents (32). MN tests ensure a measure of chromosome loss and chromosome breakage or non-disjunction in aneugenic and clastogenic events $(33,34)$. And, aneuploidy and/or chromosomal instability that is known as basic contributor to tumor progression may cause by damaged DNA (35). Our results are in accordance with previous reports. In a previous study we investigated that genotoxic activities of the potasium tetra borate and suggested that potasium tetra borate was not mutagenic shown by the absence of $\mathrm{MN}$ and $\mathrm{CA}$ induction in human lymphocytes (14). Again, the genotoxic effects of B compounds (coleminate, ulexite, boric acid and borax) were determined by SCE and $\mathrm{MN}$ assays in human blood cultures. Our results showed that these B compounds had also no mutagenic effect (24). Landolph (36) reported that borax samples (crude, refined and kernite) were not significantly mutagenic effect in $\mathrm{C} 3 \mathrm{H} / 10 \mathrm{~T} 1 / 2$ fibroblasts of mouse embryo and diploid human foreskin fibroblasts. Boric acid did not induce CA or SCE ovary cells of Chinese hamster (37). Moreover, boric acid did not show mutagenic effect in the mouse lymphoma (38), the unscheduled DNA synthesis tests in primary rat hepatocytes (39), or in the in vivo MN test in mice (40). In contrast to our findings, a study by ECETOC (1995) demonstrated sodium perborate was found weakly mutagenic in only one strain of Salmonella (41).

Antioxidant systems have very important role in healthy life of human and animals $(42,43,29)$. The measuring of TAC gives more reliable biological information than individual antioxidant (44). In the present study, according to our knowledge, antioxidant capacity of ATT tested for the first time.

The present study is performed to evaluate oxidative/antioxidative potential of ATT by using TAC and TOS assays. ATT (at concentrations of 5, 10,20 and $40 \mathrm{mg} / \mathrm{L}$ ) led to increases of TAC level. TAC has an ability to measure all antioxidants in organism $(44,45)$. In parallel to our findings, so recent study indicated that potassium tetra borate caused significant increase on TAC levels at low concentrations in cultured human blood cells (14).

Turkez et al. (24) reported that boric acid, borax, colemanite and ulexite caused significant increases in the anti-oxidant enzyme activities (catalase, superoxide dismutase, glutathione-S-transferase glutathione peroxidase, and glucose-6-phosphate dehydrogenase) of erythrocytes. Also, the levels of total glutathione and TAC significantly increased. In earlier study with regard B compound, reported that calcium fructoborate have antioxidant effect on human keratinocyte cells (46). Hunt and Idso (47) stated that 
boron prevents oxidative damage by increasing of glutathione and its analogues or by supporting the other neutralizing agents. In another paper, Griffith et al. (48) indicated that increased renal glutathione, which is an important antioxidant in plants, animals, fungi and some bacteria and archaea, status related to serine-borate in mice.

In addition, Scorei and Rotaru (49) pointed out that calcium fructoborate decreased the formation of superoxide ions in cultured cells subjected to oxidative stress. On the other hand ATT did not change TOS levels at all applied concentrations. In parallel to our findings, boric acid, borax, colemanite and ulexite did not affect the malondialdehyde (MDA) level of blood which is an important biomarker of oxidative stress (24).

Conclusion

As a conclusion, our results clearly proved that ATT is non-genotoxic and it has an important antioxidant potential. Moreover, it did not change TOS levels at all concentrations. However, more in vivo studies are required before it can be used to environmental and biological applications.

Acknowledgments: The authors are grateful to all volunteers for the blood samples.

Conflict of interest: The authors declare that there are no conflicts of interest

\section{References}

1. Howe PD. A review of boron effects in the environment. Bio Trace Elem Res. 661(998) 153-166

2. Rainey, C.J, Nyquist, L.A, Christensen, R.E, Strong, P.L, Culver B.D, Coughlin, J.R. Daily boron intake from the American diet. J The Am Diet Ass. 99 (1999) 335-40.

3. Hunt, C.D. Regulation of enzymatic activity: One possible role of dietary boron in higher animals and humans. Bio Trace Elem Res. 66 (1998) 205-225.

4. Sutherland, B., Leslie, R., Woodhouse, P.S., Janet, C.K. Boron balance in humans. J Trace Elemt Exp Med. 12 (1999) 271284.

5. Barranco W.T., Eckhert C.D. Boric acid inhibits human prostate cancer cell proliferation. Cancer Lett. 216 (2004) 21-29.

6. Cui, Y., Winton, M.I., Zhang, Z.F., Rainey, C., Marshall, J. De., Kernion, J.B., Eckhert, CD. Dietary boron intake and prostate cancer risk. Onc Rep 11(2006) 887-892.

7. Yazbeck, C., Kloppmann, W., Cottier, R., Sahuquillo, J., Debotte, G., Huel, G. Health impact evaluation of boron in drinking water: a geographical risk assessment in Northern France. Env Geochem Healt. 27 (2005) 419-427.
8. Newnham, R.E. The role of boron in human nutrition. J App Nut 46 (1994) 81-85.

9. Chapin, R.E., Warren, W.K., Mary, A.K., Harriett, M., Beth, G., Robert, N.W., Ralph W, Michael, R.E. The effects of dietary boron on bone strength in rats. Fundem and App Tox. 35 (1997) 205-215.

10. Devirian, T.A., Volpe, S.L. The physiological effect of dietary boron. Crit Rev of Food Sci and Nut. 43 (2003) 219-231.

11. Türkez, H., Geyikoğlu, F., Tatar, A. Borax counteracts genotoxicity of aluminum in rat liver. Tox and Ind Health 29 (2013) 775-779.

12. Gallardo-Williams, M.T., Maronpot, R.R., Wine, R.N., Brunssen, S.H., Chapin, R.E. Inhibition of the enzymatic activity of prostate-specific antigen by boric acid and 3Nitrophenyl boronic acid. Prostate 54 (2003) 44-49

13. Korkmaz, M., Uzgören, E., Bakırdere, S., Aydın, F., Ataman, O.Y. Effects of dietary boron on cervical cytopathology and on micronucleus frequency in exfoliated buccal cells. Envir Tox 22 (2007) 17-25.

14. Çelikezen, F.Ç., Turkez, H., Togar, B., Izgi, M.S.. DNA damaging and biochemical effects of potassium tetra borate. EXCLI J 13 (2014) 446-450.

15. Nielsen, F. The emergence of boron as nutritionally important throughout the lifecycle. Nutrition 16 (2000) 512514.

16. Nielsen, F. Biochemical and physiological consequences of boron deprivation in humans. Envi Health Persp 102 (1994) 59-63.

17. Armstrong, T., Spears, J. Effect of boron supplementation of pig diets on the production of tumor necrosis factor-a and interferon-c. J Ani Sci. 81 (2003) 2552-2561.

18. Ince, S., Kucukkurt, I., Cigerci, I.H., Fidan, A.F., Eryavuz, A. The effects of dietary boric acid and borax supplementation on lipid peroxidation, antioxidant activity, and DNA damage in rats. J Trace Elem in Med and Bio 24 (2010) 161-164.

19. Geyikoglu, F., Turkez, H. Boron compounds reduce vanadium tetraoxide genotoxicity in human lymphocytes. Envir Tox and Pharm 26 (2008) 342-347.

20. Türkez, H., Tatar, A., Hacimuftuoglu, A. Boric acid as a protector against paclitaxel genotoxicity Acta Biochim Pol 1 (2010) 95-97

21. Carpenter, S.B., Kistler, R.B. Industrial Minerals and Rocks: Boron and Borates. Littleton, Colorado, Society for Mining, Metallurgy, and Exploration, Inc. (2006)

22. Demir, H., Sahin, Ö., İzgi, M.S., Fıratoğlu, H. Production of granular Boron oxide by calcation of ammonium tetrahydrate. Thermochim Acta. 445 (2006) 1-6.

23. Snell, D.F., Hilton, C.L. Encyclopaedia of Industrial Chemical Analysis. New York. (1968)

24. Türkez, H., Geyikoğlu, F., Tatar, A., Keleş, S., Ozkan, A. Effects of some boron compounds on peripheral human blood. Zeits für Natur 62c (2007) 889-896

25. Evans, H.J., O'Riordan, M.L. Human peripheral blood lymphocytes for the analysis of chromosome aberrations in mutagen tests. Mut Res. 31 (1975) 135-148. 
26. Fenech, M., Morley, A.A. Measurement of micronuclei in lymphocytes. Mut Res. 147 (1985) 29-36.

27. Fenech, M. The cytokinesis-block micronucleus technique: detailed description of the method and its application to genotoxicity studies in human populations. Mut Res 285 (1993) 35-44.

28. IPCS (International Program on Chemical Safety). American Oil Environmental Health Criteria 46. Guidelines for the study of genetic effects in human populations. Geneva, WHO (1985) 45-54.

29. Türkez, H., Togar, B.. The genotoxic and oxidative damage potential of olanzapine in vitro. Tox and Ind Health. 9 (2010) 583-538

30. Geyikoglu, F., Turkez, H. Protective effect of sodium selenite on genotoxicity to human whole blood cultures induced by aflatoxin B-1. Braz Arch Bio and Tech 6 (2005) 905-910.

31. Rieznichenko, L.S., Dybkova, S.M., Gruzina, T.G., Ulberg, Z.R., Todor, I.N., Lukyanova, N.Y., Shpyleva, S.I., Chekhun, V.F. Gold nanoparticles synthesis and biological activity estimation in vitro and in vivo. Exp Onc 34 (2012) 25-28.

32. Padovani, L., Stronati, L., Mauro, F., Testa, A., Appolloni, M., Anzidei, P., Caporossi, D., Tedeschi, B., Vernole, P. Cytogenetic effects in lymphocytes from children exposed to radiation fall-out after the chernobyl accident. Muta Res 395 (1997) 249-254.

33. Karaman, A., Kadı, M., Kara, F. Sister chromatid exchange and micronucleus studies in patients with Behcet's disease. CutanPath 36 (2009) 831-837.

34. Türkez, H., Geyikoglu, F., Mokhtar, Y.I. Eicosapentaenoic acid protects against 2,3,7,8-tetrachlorodibenzo-p-dioxininduced hepatic toxicity in cultured rat hepatocytes. Cytotech 64 (2012) 15-25

35. Erol, A. Systemic DNA damage response and metabolic syndrome as a premalignant state. Cur Mol Med. 10 (2010) 321-334

36. Landolph, J.R. Cytotoxicity and negligible genotoxicity of borax and borax ores to cultures mammalian cells. Am J Ind Med. 7 (1985) 31-43

37. NTP (National Toxicology Program). Toxicology and Carcinogenesis Studies of Boric Acid(CAS No. 10043-35-3) in B6C3F1 Mice (Feed Studies). Research Triangle Park, NC: US Department of Health and Human Services. (1987).
38. Rudd, C.J. Mouse lymphoma cell mutagenesis assay (tk +/-) of boric acid. US Borax Corp, MRID N 4203902. (1991).

39. Bakke, J.P. Evaluation of the potential of boric acid to induce unscheduled DNA synthesis, in the in vitro hepatocyte DNA repair assay using the male F-344 rat. US Borax Corp. MRID $N^{\circ}$ 42038903. (1991)

40. O'Loughlin, K.G. Bone Marrow Erythrocyte Micronucleus Assay of Boric Acid in Swiss-Webster Mice. (Unpublished study) Submitted by U.S. Borax Corp. MRID No. 42038904.Cited In: U.S. EPA, 2004. (1991).

41. ECETOC. Technical Report Reproductive and general toxicology of some inorganic borates and risks assessment for human beings. European Centre for Ecotoxicology and Toxicology of Chemicals, Brussels. .(1995).

42. Geyikoglu, F., Turkez, H., Keles, S.M. The role of fruit juices in the prevention of aluminum sulphate toxicity in human blood in vitro. Fres Envi Bul, 10 (2005) 878-883.

43. Bohloli, M., Uzun, H., Aytaç, E., Toklu, A.S., Paksoy, M., Durak, H., İpek, T. Hyperbaric oxygen (HBO) therapy after partial hepatectomy: an experimental study on oxidative stress in rats. Scand J Lab Ani Sci 34 (2007) 131-40.

44. Ghiselli, A., Serafini, M., Natella, F., Scaccini, C. Total antioxidant capacity as a tool to assess redox status: critical view and experimental data. Free Rad Bio and Med. 29 (2000) 1106-1114.

45. Somogyi, A., Rosta, K., Pusztai, P., Tulassay, Z., Nagy, G. Antioxidant measurements. Phys Measur. 28 (2007) 41-55.

46. Scorei, R., Cimpoiasu, V.M., Iordachescu, D. In vitro evaluation of the antioxidant activity of calcium fructoborate. Bio Trace Elem Res. 107 (2005) 127-34.

47. Hunt, C.D., Idso, J. Dietary boron as a physiological regulator of the normal inflammatory response: a review and current research progress. J of Trace Elem and Exp Med. 12 (1999) 221-33.

48. Griffith, O.W., Bridges, R.J., Meister, A. Evidence that the gamma-glutamyl cycle functions in vivo using intracellular glutathione: effects of amino acids and selective inhibition of enzymes. Pro Nat Acad Sci 75 (1978) 5405-5408.

49. Scorei, R., Rotaru, P.. Calcium fructoborate: potential antiinflammatory agent. (published online ahead of print January 28, 2011). Bio Trace Elem Res doi:10.1007/s12011011-8972-6. (2011)

Copyright (C) 2014 The Author(s); This is an open-access article distributed under the terms of the Creative Commons Attribution License (http://creativecommons.org/licenses/by/4.0), which permits unrestricted use, distribution, and reproduction in any medium, provided the original work is properly cited. All Rights reserved by international journal of Natural Science and Discovery and Lycians Press Inc. 